\title{
Warning Index System of Multi-emergency Coupling on Cluster Analysis
}

\author{
Fu WANG ${ }^{1, a}$, YangYANG ${ }^{1}$ and JieLI $I^{1,2^{\star}}$ \\ ${ }^{1}$ Transportation Research Center, Wuhan Institute of Technology, Wuhan Hubei 430073,China \\ ${ }^{2}$ School of Civil Engineering \& Mechanics, Huazhong University of Science \&Technology, Wuhan \\ Hubei 430074, China \\ a550616898@qq.com
}

Keywords: Many emergencies coupling, Urban traffic, Traffic warning index, Matlab cluster analysis

\begin{abstract}
To evaluate emergency traffic warning, it is necessary to establish a set of accurate, concise, easy operation indexes system. Influence of unexpected events on transportation system is complex, involving many indexes, the early warning evaluation calculation is complex, and calculation accuracy is not high using all indexes. According to the characteristics of emergency nature and transportation system, the comprehensive index system was established including emergency coupling city traffic crisis alarm and warning, then the comprehensive index system was analyzed by clustering analysis of Matlab for the order of importance of each index, the main early warning index was screened out to establish the index system for evaluation calculation. Through the cluster analysis of Matlab, the initial index system including 31 indexes turned into the index system consists of only 16 main index, which helps to speed up the early warning evaluation speed, to improve the efficiency of emergency decision.
\end{abstract}

\section{Introduction}

Influence of emergency on transportation system is complex and changeable, which involves many indicators, if more than one event gathered together, things will become more complicated. Excessive difficulty index and the difficult of index gained to make traffic warning is difficult to achieve. Thus, too many indicators need to be screened, selected major impact indicators for early warning assessment that accelerate warning speed, but also can improve the accuracy of early warning [1].

Combined with relevant research literature, fieldwork analysis and consulting experts,the comprehensive index system was established including emergency coupling city traffic crisis evaluation index system[2] .Then through the cluster analysis of Matlab, we can classify the importance of the index factors and determine the order[3].Next evaluation index system warning is determined after the final optimization[4].

\section{The Preliminary Index System Established.}

When selecting indexes, we should pay attention to the sensitivity of indexes, the principle of scientific; reality and reliability [5].To evaluate emergency traffic warming, it is necessary to consider a lots of factors. We need to find out traffic crisis alarm and analyze warming, and finally the situation of city traffic would be determined. The main elements of early warning evaluation is concerned that "traffic", if you want to correctly predict more unexpected events coupled with the urban transport system interaction, which possibly produce urban transport police intelligence[6].We need to consider the traffic crisis alarm and warming from two aspects-emergency coupling and traffic system. According to the related literature [1-8] and consulting experts, we find that it contains three levels. Primary index system has been established as the following table 1. 
Table 1. Preliminary index system

\begin{tabular}{|c|c|c|c|}
\hline $\begin{array}{l}\text { Target } \\
\text { layer }\end{array}$ & $\begin{array}{l}\text { Property } \\
\text { layer }\end{array}$ & Evaluation layer & Index layer \\
\hline \multirow{30}{*}{$\begin{array}{l}\text { Evalua } \\
\text { tion } \\
\text { index } \\
\text { system } \\
\text { of city } \\
\text { transp } \\
\text { ortatio } \\
\text { n } \\
\text { pre-wa } \\
\text { rning } \\
\text { under } \\
\text { multi- } \\
\text { emerg } \\
\text { ency } \\
\text { coupli } \\
\text { ng } \\
\text { A }\end{array}$} & \multirow{18}{*}{$\begin{array}{l}\text { Alarm } \\
\text { source of } \\
\text { city } \\
\text { transporta } \\
\text { tion crisis } \\
\text { under } \\
\text { multi-eme } \\
\text { rgency } \\
\text { coupling } \\
\text { B }_{1}\end{array}$} & \multirow{8}{*}{$\begin{array}{l}\text { Considering alarm } \\
\text { source that causes } \\
\text { transportation } \\
\text { crisis from the } \\
\text { perspective of } \\
\text { multi-emergency } \\
\text { coupling } \\
\mathrm{C}_{1}\end{array}$} & $\begin{array}{l}\text { The degree of concern from city policies on } \\
\text { pre-warning under accident coupling } \mathrm{D}_{1}\end{array}$ \\
\hline & & & The types of accident coupling $\mathrm{D}_{2}$ \\
\hline & & & $\begin{array}{l}\text { The phase of frequently occurring of accident } \\
\text { coupling } D_{3}\end{array}$ \\
\hline & & & $\begin{array}{l}\text { The activity degree of hazard factors that cause } \\
\text { accident coupling } \mathrm{D}_{4}\end{array}$ \\
\hline & & & The amount of sites that exist accident threat $\mathrm{D}_{5}$ \\
\hline & & & $\begin{array}{l}\text { The occurrence rate of public health events } \\
\text { under accident coupling } \mathrm{D}_{6}\end{array}$ \\
\hline & & & $\begin{array}{l}\text { The occurrence rate of public safety events } \\
\text { under accident coupling } D_{7}\end{array}$ \\
\hline & & & The rescue capacity of accident coupling $\mathrm{D}_{8}$ \\
\hline & & \multirow{10}{*}{$\begin{array}{l}\text { Considering alarm } \\
\text { source that causes } \\
\text { transportation } \\
\text { crisis from the } \\
\text { perspective } \\
\text { transportation of } \\
\text { system } \\
\mathrm{C}_{2}\end{array}$} & $\begin{array}{l}\text { The completeness of road traffic guidance } \\
\text { information systemD }\end{array}$ \\
\hline & & & The effectiveness of traffic guidance center $\mathrm{D}_{10}$ \\
\hline & & & $\begin{array}{l}\text { The damage rate of monitors equipment at } \\
\text { junctions } D_{11}\end{array}$ \\
\hline & & & $\begin{array}{l}\text { The traffic regulation rate under accident } \\
\text { coupling } D_{12}\end{array}$ \\
\hline & & & The damage rate of signal lampsD $\mathrm{D}_{13}$ \\
\hline & & & The control rate of roads $\mathrm{D}_{14}$ \\
\hline & & & The blocking rate of junctions $\mathrm{D}_{15}$ \\
\hline & & & The completeness of roads $\mathrm{D}_{16}$ \\
\hline & & & The density of road network $\mathrm{D}_{17}$ \\
\hline & & & $\begin{array}{l}\text { The average running speed in the road network } \\
D_{18}\end{array}$ \\
\hline & \multirow{12}{*}{$\begin{array}{l}\text { Alarm } \\
\text { aura of } \\
\text { city } \\
\text { transporta } \\
\text { tion crisis } \\
\text { under } \\
\text { multi-eme } \\
\text { rgency } \\
\text { coupling } \\
\mathrm{B}_{2}\end{array}$} & \multirow{6}{*}{$\begin{array}{l}\text { Considering alarm } \\
\text { aura that causes } \\
\text { transportation } \\
\text { crisis from the } \\
\text { perspective of } \\
\text { multi-emergency } \\
\text { coupling } \\
\mathrm{C}_{3}\end{array}$} & $\begin{array}{l}\text { The degree of influence from meteorological } \\
\text { factors on situation under accident coupling } D_{19}\end{array}$ \\
\hline & & & The diffusion scope of the hazard source $\mathrm{D}_{20}$ \\
\hline & & & $\begin{array}{l}\text { The degree of the possible casualties due to } \\
\text { accident coupling } \mathrm{D}_{21} \\
\text { The degree of the possible property loss due to } \\
\text { accident coupling } \mathrm{D}_{22}\end{array}$ \\
\hline & & & $\begin{array}{l}\text { The time from single accident to accident } \\
\text { coupling } D_{23}\end{array}$ \\
\hline & & & $\begin{array}{l}\text { The time span of accident coupling from the } \\
\text { occurrence to the deterioration } D_{24}\end{array}$ \\
\hline & & & $\begin{array}{l}\text { The possible time of continuous influence due } \\
\text { to accident coupling } D_{25}\end{array}$ \\
\hline & & \multirow{6}{*}{$\begin{array}{l}\text { Considering alarm } \\
\text { aura that causes } \\
\text { transportation } \\
\text { crisis from the } \\
\text { perspective } \\
\text { transportation of } \\
\text { system } \\
\mathrm{C}_{4}\end{array}$} & $\begin{array}{l}\text { The degree of influence from meteorological on } \\
\text { traffic } \mathrm{D}_{26}\end{array}$ \\
\hline & & & $\begin{array}{l}\text { The degree of traveling mode change under } \\
\text { accident coupling } D_{27}\end{array}$ \\
\hline & & & $\begin{array}{l}\text { The degree of vehicle queue extension under } \\
\text { accident coupling } D_{28}\end{array}$ \\
\hline & & & $\begin{array}{l}\text { The degree of average running speed change } \\
\text { under accident coupling } \mathrm{D}_{29}\end{array}$ \\
\hline & & & $\begin{array}{l}\text { The degree of traffic moving on the set rescue } \\
\text { routes } D_{30}\end{array}$ \\
\hline & & & $\begin{array}{l}\text { The scope of traffic control under accident } \\
\text { coupling } \mathrm{D}_{31}\end{array}$ \\
\hline
\end{tabular}




\section{The Importance of Clustering Index Factor Analysis Based on Matlab}

Using Matlab to analysis indexes, we take the clustering method of "The shortest distance method system of distance". The purpose of clustering analysis is to determine the importance of each index in the index system to the previous layer, so we can fuzzy sort the importance of each index in each level.[9,10]

Matlab software program system for clustering method shortest distance is table2.

Table2.Matlab software program system for clustering method shortest distance

\begin{tabular}{|c|c|c|c|}
\hline$>X=[]$ & $\begin{array}{l}\text { \%Scoring matrix of experts for } \\
\text { relative importance index }\end{array}$ & $\begin{array}{l}>> \\
B X=\operatorname{zscore}(X)\end{array}$ & $\begin{array}{l}\% \text { Standardized } \\
\text { data matrix }\end{array}$ \\
\hline$>>Y=\operatorname{pdist}(X)$ & $\begin{array}{l}\text { \% Use Euclidean distance to } \\
\text { calculate the distance between } \\
\text { any two indicators }\end{array}$ & $\begin{array}{l}>> \\
D=\text { squareform }(Y)\end{array}$ & $\begin{array}{l}\% \quad \text { Euclidean } \\
\text { distance matrix }\end{array}$ \\
\hline $\begin{array}{l}>> \\
Z=\operatorname{linkage}(Y)\end{array}$ & $\begin{array}{l}\text { \%The shortest distance } \\
\text { computing systems clustering } \\
\text { tree method }\end{array}$ & $>_{T}=$ cluster $(Z, n)$ & $\begin{array}{l}\% \text { Clustering } \\
\text { classification, } \\
\text { divided into } \mathrm{n} \\
\text { classes }\end{array}$ \\
\hline$>>$ find $(T==1)$ & $\begin{array}{l}\% \text { The first class of elements } \\
\text { found }\end{array}$ & $\begin{array}{l}>> \\
{[H, T]=\operatorname{dendrogram}(Z}\end{array}$ & $\begin{array}{l}\% \quad \text { Graphical } \\
\text { output clustering }\end{array}$ \\
\hline
\end{tabular}

According to consulting the five experts(the field of emergency management and traffic management), the scoring matrix were gained for the importance of index factors in software programming of calculation.

Fuzzy expert scoring in five languages for the evaluation criteria [9], namely a significant impact on the five points of the layer produced on behalf of indicators;

Five points represent that the impact of index on previous layer is great, four points represent that the index has big impact on previous layer, three represent that the index has significant impact on previous layer, two represent that the impact of index on previous layer is small. One represent that index has little impact on the previous layer [11,12].

In the program,3 was assigned to $\mathrm{n}$. It means that the indexes were divided into three categories according to the relative importance. Firstly, the index factor is imperative relative to the evaluation layer. Secondly, the index factors are important relative to the evaluation layer. Thirdly,the index factors is not that important to evaluation layer.

1. The clustering analysis about index factorsin $C_{1}$.

Based on experts graded the index factors in $C_{1}$,After a program to calculate the clustering diagram as shown in figure.

According to clustering analysis, we choose 2.4 as standard values. The preliminary judgment is that the indexes of 3,8,1,2 are imperative,5,6,7 are important and 4 is generally important. The fuzzy index sort of importance relative to $\mathrm{C} 1$ is $(3,8,1,2),(5,6,7), 4$.

2 .The clustering analysis about index factors in $\mathrm{C}_{2}$.

Based on experts graded the index factors in $\mathrm{C}_{2}$, after a program to calculate the clustering diagram as shown in figure.

According to clustering analysis, we choose 2.4 as standard values. The preliminary judgment is that the indexes of 7,10,1,2,3 are imperative,5,6,9,8 are important and 4 is generally important. The fuzzy index sort of importance relative to C2 is(7,10,1,2,3),(5,6,9,8),4. 


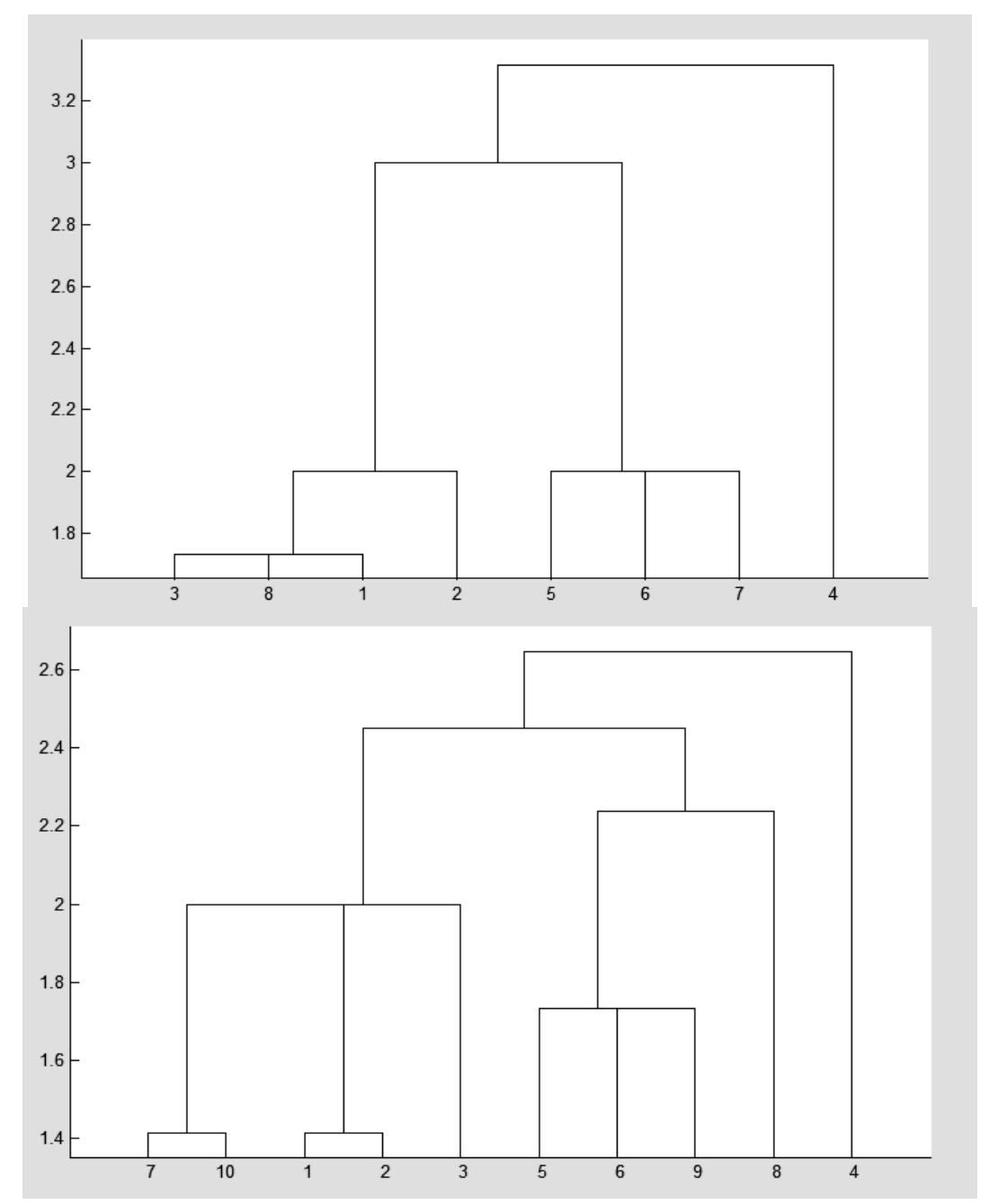

Fig. 1. causing traffic crisis alarm Fig.2. causing crisis warning index importanceindex clustering figureimportance clustering figure.

3. The clustering analysis about index factors in C3.

Based onexperts graded the index factors in C3,after a program to calculate the clustering diagram as shown in figure.

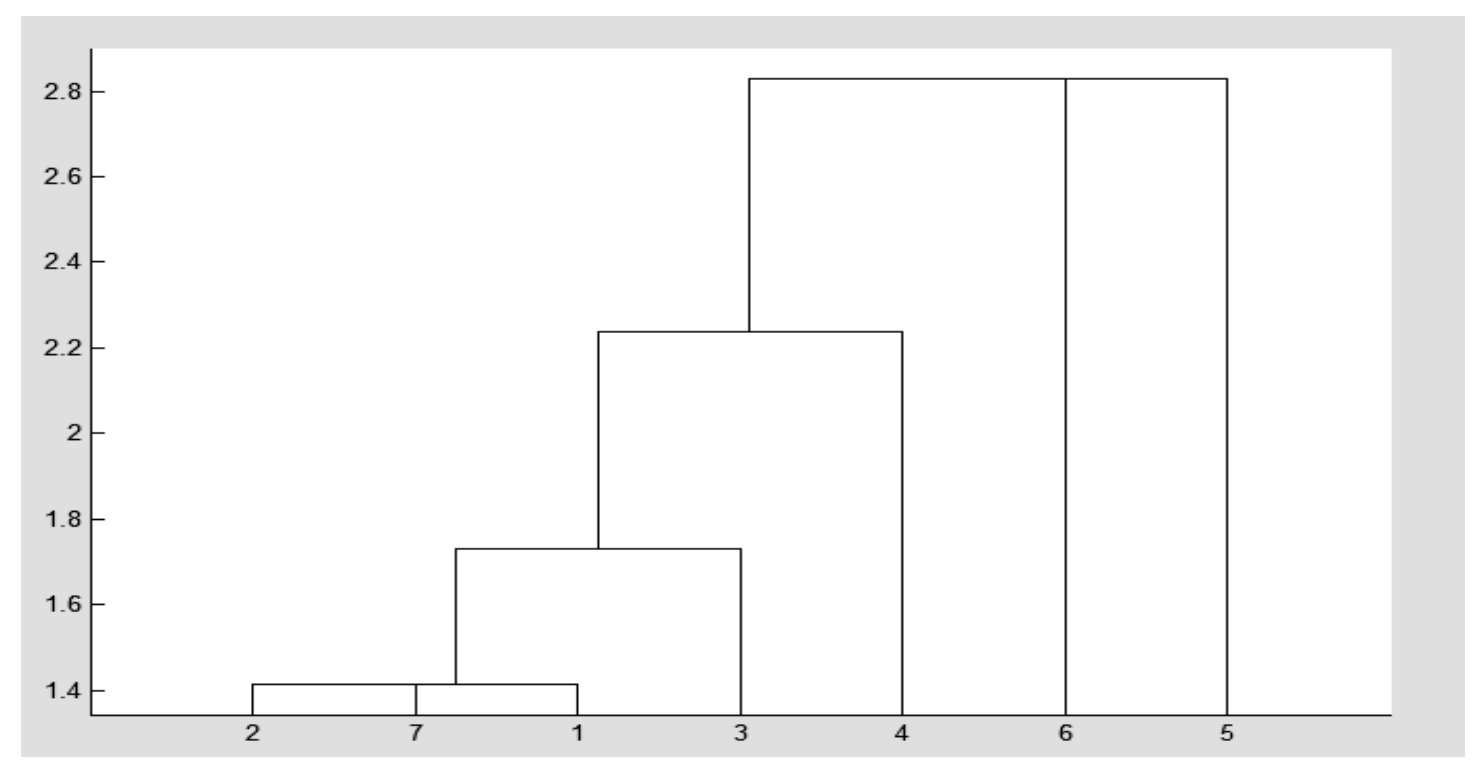

Fig. 3. causing traffic crisis warning index importance clustering figure. 
According to clustering analysis,we choose 2.4 as standard values. The preliminary judgment is that the indexes of 2,7,1,3,4 are imperative, 6 are important and 5 is generally important.The fuzzy index sort of importance relative to $\mathrm{C} 3$ is(2,7,1,3,4),6,5.

4 .The clustering analysis about index factors in $\mathrm{C}_{4}$.

Based onexperts graded the index factors in $\mathrm{C}_{4}$, After a program to calculate the clustering diagram as shown in figure.

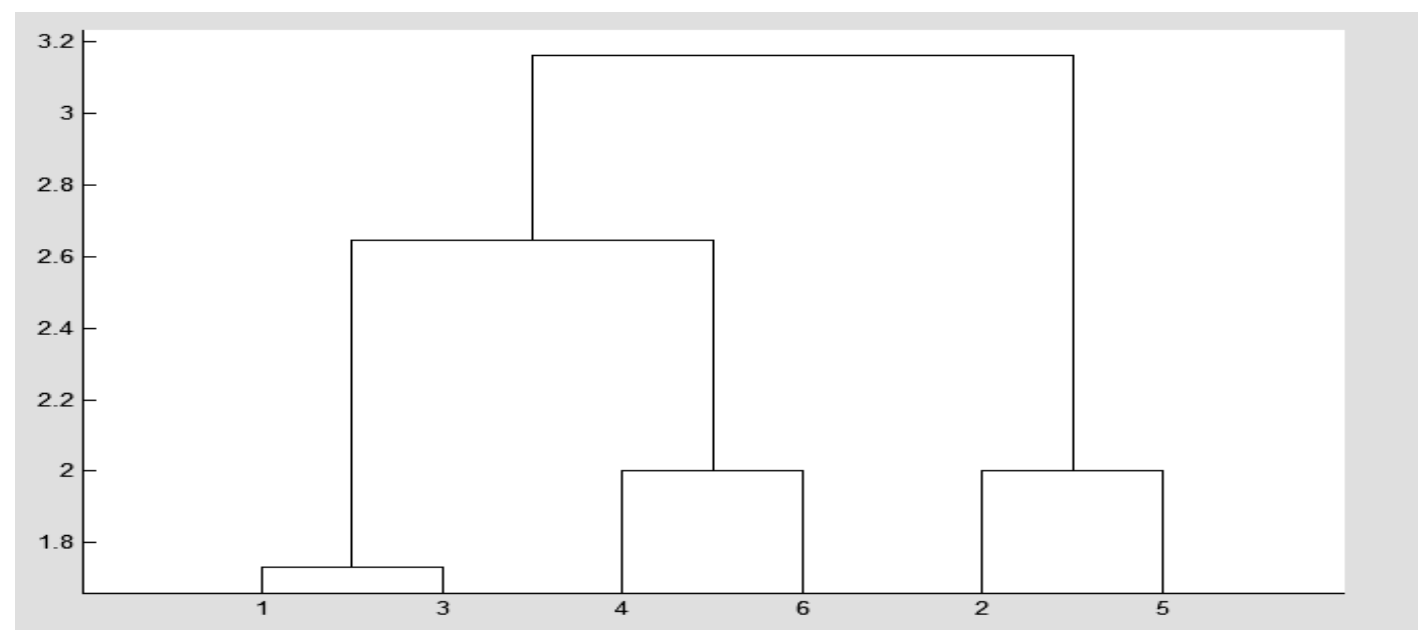

Fig. 4.causing crisis warning index importance clustering figure.

According to clustering analysis,we choose 2.4 as standard values. The preliminary judgment is that the indexes of 1,3 are imperative,4,6 are important and2,5 is generally important.The fuzzy index sort of importance relative to $\mathrm{C}_{4}$ is $(1,3),(4,6),(2,5)$.

\section{After the clustering analysisby Matlab,the system of indexes was established.}

After clustering analysis,the fuzzy sort which is related to the importance of indexes was determined.With the suggestion from experts, indexes improvement were obtained, the existence of indicators clearly inappropriate were re-examined, if there were missing important indexes and the important indexesfrom clustering analysis filtered out (table 3).

Table 3. Clustering analysis based on Matlab the index system was establish

\begin{tabular}{|c|c|c|c|}
\hline $\begin{array}{l}\text { Target } \\
\text { layer }\end{array}$ & $\begin{array}{l}\text { operty } \\
\text { yer }\end{array}$ & Evaluation layer & Index layer \\
\hline \multirow{9}{*}{$\begin{array}{l}\text { Evaluati } \\
\text { on index } \\
\text { system } \\
\text { of city } \\
\text { transport } \\
\text { ation } \\
\text { pre-warn } \\
\text { ing } \\
\text { under } \\
\text { multi-e } \\
\text { mergenc } \\
\text { y } \\
\text { coupling } \\
\text { A }\end{array}$} & \multirow{8}{*}{$\begin{array}{l}\text { Alarm } \\
\text { source of } \\
\text { city } \\
\text { transport } \\
\text { ation } \\
\text { crisis } \\
\text { under } \\
\text { multi-em } \\
\text { ergency } \\
\text { coupling } \\
\mathrm{B}_{1}\end{array}$} & \multirow{4}{*}{$\begin{array}{l}\text { Considering alarm } \\
\text { source that causes } \\
\text { transportation } \\
\text { crisis from the } \\
\text { perspective of } \\
\text { multi-emergency } \\
\text { coupling } \\
\text { C }_{1}\end{array}$} & $\begin{array}{l}\text { The degree of concern from city policies on } \\
\text { pre-warning under accident coupling } D_{1}\end{array}$ \\
\hline & & & The types of accident coupling $\mathrm{D}_{2}$ \\
\hline & & & $\begin{array}{l}\text { The phase of frequently occurring of accident } \\
\text { coupling } D_{3}\end{array}$ \\
\hline & & & The rescue capacity of accident coupling $\mathrm{D}_{4}$ \\
\hline & & \multirow{4}{*}{$\begin{array}{l}\text { Considering alarm } \\
\text { source that causes } \\
\text { transportation } \\
\text { crisis from the } \\
\text { perspective of }\end{array}$} & $\begin{array}{l}\text { The completeness of road traffic guidance } \\
\text { information system } \mathrm{D}_{5}\end{array}$ \\
\hline & & & $\begin{array}{l}\text { The effectiveness of traffic guidance center } \mathrm{D}_{6} \\
\text { The damage rate of monitors equipment at } \\
\text { junction } \mathrm{D}_{7}\end{array}$ \\
\hline & & & The blocking rate at junction $\mathrm{D}_{8}$ \\
\hline & & & $\begin{array}{l}\text { The average running speed of vehicles in the } \\
\text { road network } D_{9}\end{array}$ \\
\hline & $\begin{array}{l}\text { Alarm } \\
\text { aura of }\end{array}$ & $\begin{array}{l}\text { Considering alarm } \\
\text { aura that causes }\end{array}$ & $\begin{array}{l}\text { The degree of influence from meteorological } \\
\text { on situation under accident coupling } D_{10}\end{array}$ \\
\hline
\end{tabular}




\begin{tabular}{|c|c|c|}
\hline \multirow{6}{*}{$\begin{array}{l}\text { city } \\
\text { transport } \\
\text { ation } \\
\text { crisis } \\
\text { under } \\
\text { multi-em } \\
\text { ergency } \\
\text { coupling } \\
\mathrm{B}_{2}\end{array}$} & \multirow{4}{*}{$\begin{array}{l}\text { transportation } \\
\text { crisis from the } \\
\text { perspective of } \\
\text { multi-emergency } \\
\text { coupling } \\
\mathrm{C}_{3}\end{array}$} & $\begin{array}{l}\text { The diffusion scope of the hazard source under } \\
\text { accident coupling } \mathrm{D}_{11}\end{array}$ \\
\hline & & $\begin{array}{l}\text { The degree of the possible casualties due to } \\
\text { accident coupling } D_{12}\end{array}$ \\
\hline & & $\begin{array}{l}\text { The degree of the possible property loss due to } \\
\text { accident coupling } \mathrm{D}_{13}\end{array}$ \\
\hline & & $\begin{array}{l}\text { The possible time of continuous influence due } \\
\text { to accident coupling } \mathrm{D}_{14}\end{array}$ \\
\hline & \multirow{2}{*}{$\begin{array}{l}\text { Considering alarm } \\
\text { aura that causes } \\
\text { transportation } \\
\text { crisis from the } \\
\text { perspective } \\
\text { transportation of } \\
\text { system } \\
\mathrm{C}_{4}\end{array}$} & $\begin{array}{l}\text { The degree of influence from meteorological } \\
\text { on traffic } D_{15}\end{array}$ \\
\hline & & $\begin{array}{l}\text { The degree of vehicle queue extension under } \\
\text { accident coupling } \mathrm{D}_{16}\end{array}$ \\
\hline
\end{tabular}

\section{Conclusion}

City traffic warning, as an important part of city emergency management, can effectively pre-control the occurrence of traffic emergencies, eliminate them before getting worse, or control the further development of events. However, it's critical and difficult to determine what measures should be taken and when to operate during the process of traffic pre-warning. To solve this problem, a scientific and accurate evaluation system is required. The index system plays a key role in evaluation system. To facilitate the evaluation process and improve efficiency, evaluation indexes should not just reveal the essence of events but be easily acquired and medium in amount. This paper firstly chooses different kinds of index factors correlated with traffic warning as possible, and then subsumes these relevant indexes under the preliminary index system. The most important indexes are filtered out through simplifying the index system based on Matlab cluster analysis. The number of final established index systems has reduced from 31 to 16, which is beneficial to reflect the truth of the events and accelerate the process of pre-warning evaluation, meeting the requirements for saving time when dealing with the emergencies.

\section{References}

[1]ZHENG Ling-li. Study on indexes and methods to evaluate traffic impact degree[D].Shanghai: Tongji University,2008.

[2]WU Xing-cun. Study on urban traffic emergency management[D].Chengdu: Southwest Jiaotong University,2010.

[3]LIU Peng. Study on precaution methodology for monitoring provincial central urban publiccrisis and constructs the precaution mechanism for provincial centralurban public crisis[D].Haerbin: Harbin Engineering University,2008.

[4]Clustering analysis of Matlab program[EB/OL].

http://wenku.baidu.com/view/00d843176edb6f1aff001fea.html

[5]Han Ye-liang, Su Guo-feng, Yuan Hongyong, et al. A Collaborative Early Warning Method of Transportation During Snow Disaster Based on Fuzzy Comprehensive Evaluation[J]. Fuzzy Systems and Knowledge Discovery Seventh International Conference on, 2010, (2): 945-951.

[6]Qi Cheng, Lei Yu. Early Warning Index System for Natural Disasters Emergency Logistics Risks[J]. Logistics Engineering and Intelligent Transportation Systems International Conference on, 2010, 1-4. 
[7] LU Hua-pu. Evaluation system of urban traffic management[M].Beijing: China Communications Press,2003

[8]GE Huiling,JIAO Yang,REN Yongtai.Early warning model of groundwater level in Harbin[J].Jo urnal of Northeast Agricultural University, 2011, (2): 77-83

[9] SHAO Li-zhou, BAI Chun-jie .Index system construction on comprehensive evaluation[J].Jour nal of Naval University of Engineering, , 2008, (3): 48-52

[10]ZHU Jian-ping, ZENG Yu-yu .Analysis and Application of Qualitative Data Clustering Approa ch Based

[11] on Attribute Importance[J]. Computer Technology and Development, 2007, (12): 89-91

[12] Clustering analysis of Matlab program[EB/OL]. 